\title{
A new yellow Camellia (Theaceae) from central Vietnam
}

\author{
Dai Ngoc DO, Dung Van LUONG ${ }^{1 *}$, Chinh Duy NGUYEN ${ }^{1}$, Son Thanh HOANG ${ }^{2}$, \\ Huong Thi LE $^{3}$, Jeong Eun HAN ${ }^{4}$ and Han-Sol PARK ${ }^{4}$ \\ Faculty of Agriculture, Forestry and Fishery, Nghe An College of Economics, Nghe An 43000, Vietnam \\ ${ }^{1}$ Department of Biology, Da Lat University, Dalat 67000, Vietnam \\ ${ }^{2}$ Silviculture Research Institute, Vietnamese Academy of Forest Sciences, Hanoi 10000, Vietnam \\ ${ }^{3}$ School of Natural Science Education, Vinh University, Nghe An 43000, Vietnam \\ ${ }^{4}$ Biological and Genetic Resources Utilization Division, National Institute of Biological Resources, Incheon 22689, Korea \\ (Received 17 January 2019; Revised 5 March 2019; Accepted 22 March 2019)
}

\begin{abstract}
Camellia pukhangensis (Theaceae), a new species with yellow flowers from Quy Hop District, Nghe An Province, Vietnam, is described and illustrated. Camellia pukhangensis has nearly sessile leaves with an attenuate to caudate apex, cordate base, hirsute abaxial surface, hirsute adaxial midrib, hirsute petiole, deltate to ovate perules hairy on the outer surface, bright yellow orbicular to obovate petals hairy on the outer surface, androecium pubescent to two-thirds from the base, pubescent ovoid ovary with three (or four) locules and three (or four) pubescent styles free to the base. The morphological data support the provisional placement of C. pukhangensis in Camellia sect. Archecamellia Sealy.
\end{abstract}

Keywords: Camellia, Theaceae, new species, Vietnam

Camellia, the largest genus of Theaceae, has its center of distribution in southern China and northern Vietnam (Chang and Bartholomew, 1984). The species number from 119 to 350 , based on the opinion of various authors (Sealy, 1958; Chang and Bartholomew, 1984; Ming, 2000; Gao et al., 2005; Ming and Bartholomew, 2007). Vietnam, with more than 30 species of Camellia with yellow flowers (Le and Luong, 2016), is the center of diversity for plants with this feature. Among them are two species of yellow Camellia: C. pleurocarpa and $C$. quephongensis, in north-central Vietnam (including Thanh Hoa, Nghe An, Ha Tinh, Quang Binh, Quang Tri, and Thua ThienHue provinces). During a survey of the flora of the Pu Khang mountain range, Lien Hop Commune, Quy Hop District, Nghe An Province, we collected samples of a yellow Camellia that did not agree with either of them. After comparing it with closely related species, we determined it to be an undescribed species, which we here name $C$. pukhangensis.

\section{Taxonomic Treatment}

Camellia pukhangensis D.N. Do, D.V. Luong, S. T. Hoang
\& H.T. Le, sp. nov. (Figs. 1, 2).-TYPE: VIETNAM. Nghe An Province: Quy Hop District, 15 Jan 2018, Dai Ngoc Do \& Huong Thi Le 186 (holotype: DLU).

Shrubs or small trees, 2-8 $\mathrm{m}$ tall, evergreen; young branches hirsute, becoming glabrous mature. Leaves shortly stalked; petiole 5-8 mm long, hirsute; blades oblong, 16-24 cm long, $5.5-8 \mathrm{~cm}$ wide, base cordate; margin serrate, apex attenuate to caudate, coriaceous, abaxially hirsute, adaxially hirsute only on midrib, lateral veins 16-20 pairs, abaxial veins protruding, adaxial midrib and lateral veins sunken. Flowers $5.5-6.5 \mathrm{~cm}$ in diameter, solitary at apex of branches, sessile or subsessile; bracteole and sepals indistinguishable (perules) 11-13, deltate to ovate, $0.3-4 \mathrm{~cm}$ long, $0.2-1.8 \mathrm{~cm}$ wide, abaxially hairy, margins ciliate. Petals 10-13, orbicular to obovate, bright yellow, 3-4.5 cm long, $2.3-4 \mathrm{~cm}$ wide, abaxially hairy, united with outermost filaments $1-1.5 \mathrm{~cm}$ at base. Stamens 350-390, in 5 or 6 series, light yellow, 3-3.5 cm long, pubescent to 2/ 3 from base, outer filaments united for $1.7-2 \mathrm{~cm}$ from base to form a cup; anthers yellow, 3-3.5 $\mathrm{mm}$ long, ca. $1 \mathrm{~mm}$ wide. Ovary with 3(or 4) loculi, ovoid, light yellow, 4-4.5 mm long,

\footnotetext{
*Author for correspondence: luongvandungdl@gmail.com
} 


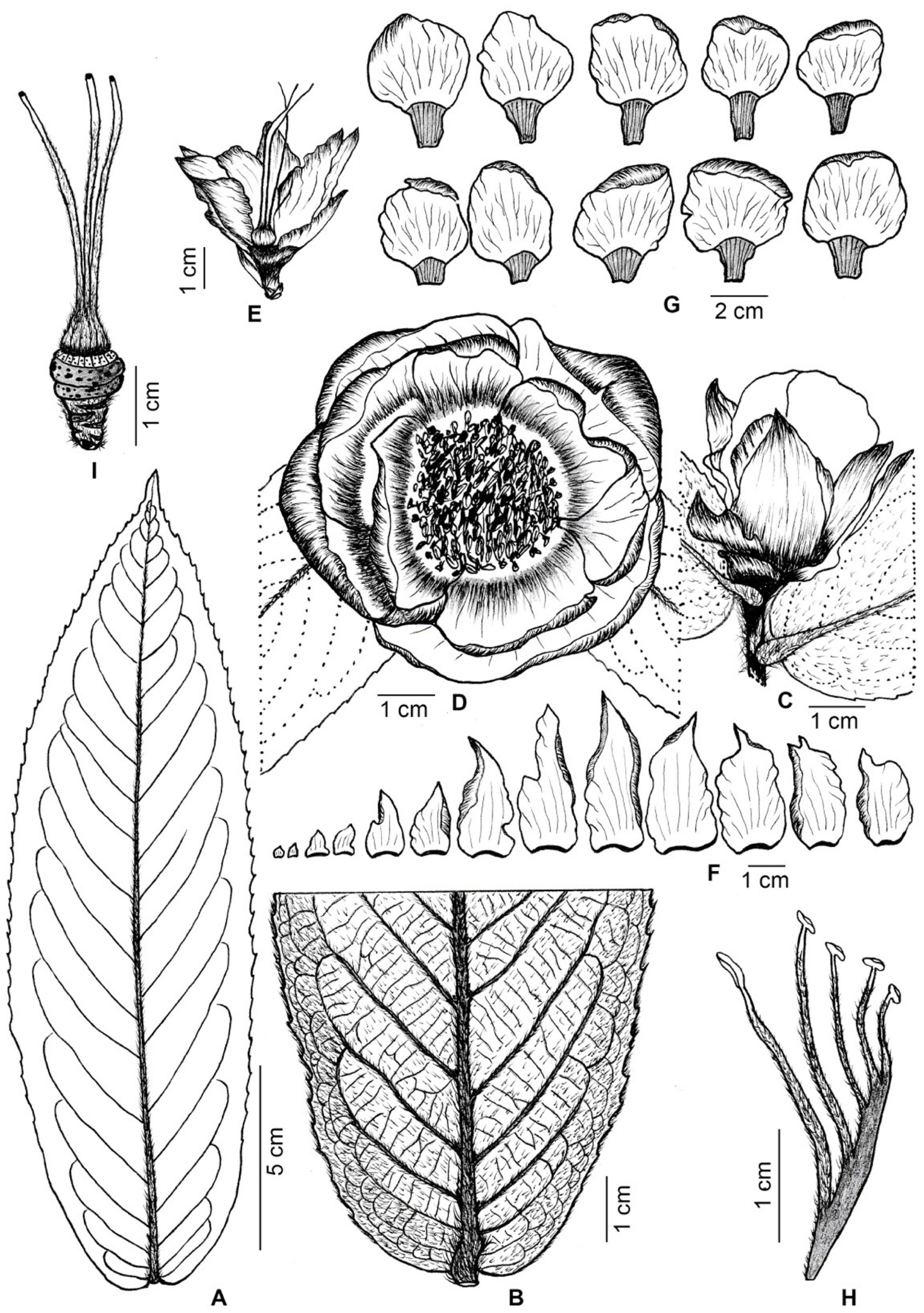

Fig. 1. Camellia pukhangensis D. N. Do, D. V. Luong, S. T. Hoang \& H. T. Le. A. Leaf, adaxial view. B. Venation detail of leaf (abaxial surface). C. Flower bud. D. Flower, top view. E. Perules and Gynoecium. F. Perules (inner surfaces shown). G. Petals (inner surfaces). H. Stamens. I. Gynoecium (other floral parts removed). Drawn by Dung Van Luong. 

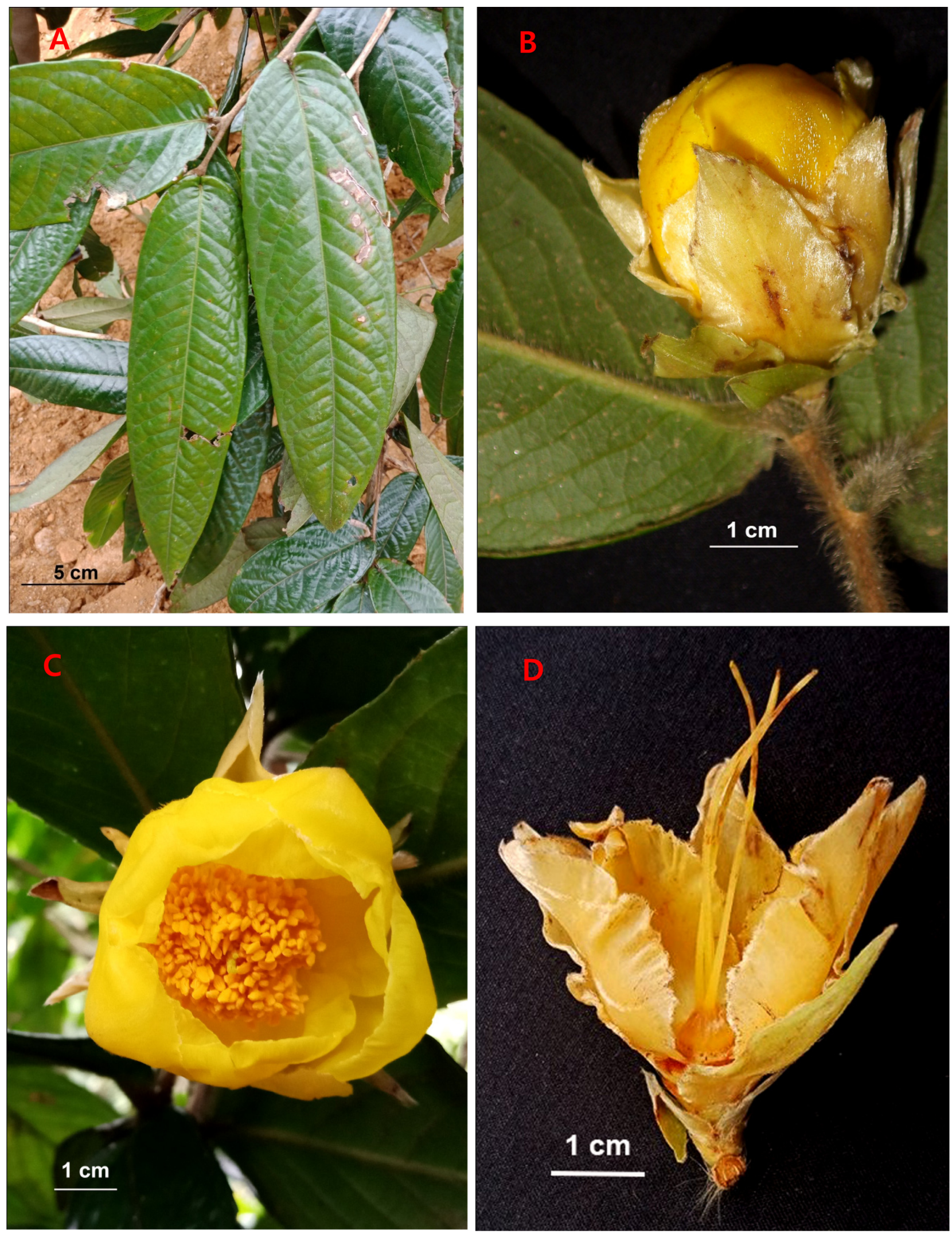

Fig. 2. Camellia pukhangensis D. N. Do, D. V. Luong, S. T. Hoang \& H. T. Le. A. Branches with leaves. B. Flower bud. C. Flower. D. Perules and Gynoecium. Photos taken by Dai Ngoc Do. 
Table 1. Morphological comparison of the species of Section Archecamellia Sealy (data partly based on Sealy, 1958; Gao et al., 2005; Yang et al., 2014)

\begin{tabular}{|c|c|c|c|c|c|}
\hline Characters & C. euphlebia & C. flava & C. petelotii & C. tonkinensis & C. pukhangensis \\
\hline Habit & Shrub, $2 \mathrm{~m}$ tall & Shrub or small tree, $2-5 \mathrm{~m}$ tall & Shrub or small tree & Shrub & Shrub or small tree, $2-8 \mathrm{~m}$ tall \\
\hline Young branches & Glabrous & Glabrous & Glabrous & Glabrous & Hirsute \\
\hline Leaf blade shape & Broadly elliptic & $\begin{array}{c}\text { Oval or oblong-elliptic or } \\
\text { oblong-oval }\end{array}$ & $\begin{array}{l}\text { Broadly oblong or } \\
\text { oblong-oval }\end{array}$ & Elliptic or broadly elliptic & Oblong \\
\hline Leaf size $(\mathrm{cm})$ & $11-14 \times(4.5)-5-6.4$ & $10.5-15 \times 3.8-5.8$ & $14.5-18 \times 4.5-7.5$ & $9-13.5 \times 2.5-5.2$ & $16-24 \times 5.5-8$ \\
\hline Leaf apex & $\begin{array}{l}\text { Shortly broadly and bluntly } \\
\text { cuspidate-acuminate }\end{array}$ & Acuminate & Shortly acuminate & $\begin{array}{l}\text { Acuminate or narrowly } \\
\text { acuminate }\end{array}$ & Attenuate to caudate \\
\hline Leaf base & Obtuse to subrounded & Shallowly cordate & Widely cuneate & Obtuse to rounded & Cordate \\
\hline Adaxial leaf surface & Glabrous & Glabrous & Glabrous & Glabrous & Hairy along midrib \\
\hline Abaxial leaf surface & Glabrous & Pubescent along midrib & Glabrous & $\begin{array}{l}\text { Puberulous along midrib near } \\
\text { base }\end{array}$ & Hirsute \\
\hline Petiole & Glabrous & Pubescent & Glabrous & Puberulous, glabrescent & Hirsute \\
\hline Flower & Solitary at end of branches & Solitary at end of branches & Solitary at end of branches & Solitary at end of branches & Solitary at end of branches \\
\hline Pedicel & ca. $5 \mathrm{~mm}$ long, glabrous & 6-9 mm long, glabrous & $1-1.2 \mathrm{~cm}$ long, glabrous & ca. $7 \mathrm{~mm}$ long, glabrous & Almost sessile \\
\hline Bracteoles & 8 , glabrous & & outer surface puberulous & 5 , outer surface puberulent & \\
\hline Sepal & 5 , outer surface velutinous & & 5 , outer surface puberulous & $\begin{array}{c}5 \text {, outer surface yellow } \\
\text { puberulent }\end{array}$ & \\
\hline Perules & & ca. 12, outer surface velutinous & & 6 , outer surface velutinous & $11-13$, outer surface pubescent \\
\hline Petal & $8-9$, outer surface velutinous & $10-13$, outer surface velutinous & ca. 14 , outer surface puberulous & 9-12, glabrous & 10-13, outer surface pubescent \\
\hline Filaments & Glabrous & Pubescent & Glabrous & Puberulent & Pubescent \\
\hline Ovary & 3 loculi, glabrous & 5 loculi, tomentose & 3 loculi, glabrous & 3 loculi, hairy & 3-(4) loculi, pubescent \\
\hline Styles & 3 , free to base, glabrous & 5 , free to base, hairy & 3 , free to base, glabrous & 3 , free to base, hairy & 3-(4), free to base, pubescent \\
\hline
\end{tabular}


4-5 mm wide, pubescent; styles 3(or 4), free to base, 3-3.2 $\mathrm{cm}$ long, pubescent. Capsules not seen.

Etymology: The specific epithet refers to the type location, $\mathrm{Pu}$ Khang Mountain in Nghe An Province, Vietnam, where it was discovered.

Phenology: Flowering from November to March; fruiting period unknown.

Distribution: Camellia pukhangensis occurs in forests in Lien Hop Commune, Quy Hop District, Nghe An Province, at altitudes of $500-900 \mathrm{~m}$. It is scattered on mountain sides and among rocks in association with species of Clusiaceae, Euphorbiaceae, Melastomataceae, Myrtaceae, and Lauraceae.

Additional specimens examined: VIETNAM. Nghe An Province: Quy Hop District, 15 Jan 2018, Dai Ngoc Do \& Huong Thi Le 187, 188 (DLU).

IUCN Red List category: Camellia pukhangensis is known from only one population of 122 individuals that occupies an area of less than $1 \mathrm{~km}^{2}$. The location is currently threatened by cutting and agricultural expansion, hence, the species is provisionally categorized as Critically Endangered (CR) B2a (IUCN, 2017).

Notes: Camellia pukhangensis is characterized by leaves abaxially hirsute and adaxially hirsute only along the midrib (section Eriandra Coh. St.); solitary flowers at the apex of branches, short pedicels, perules more than 10 (section Archecamellia Sealy); the gynoecium is 3(or 4) locular with three free styles (section Chrysantha Chang). However, species in section Eriandra are characterized by small leaves hairy only on the midrib, small white flowers, the androecium in 2 or 3 whorls and compound styles (Chang and Bartholomew, 1984; Ming and Bartholomew, 2007). Camellia pukhangensis has yellow petals, the androecium in 5 or 6 whorls and free styles. Section Chrysantha is characterized by 1-3 axillary flowers or flowers at the apex of branches, long pedicels, bracteoles and sepals distinguishable, 5-7 bracteoles, 5-7 persistent sepals, 8-12 yellow petals, the androecium in four whorls and the stamens connate into a short tube, the gynoecium glabrous or pubescent with 3-5 loculi and 3-5 free styles (Chang and Bartholomew, 1984; Ming and Bartholomew, 2007). Camellia pukhangensis has solitary, sessile or subsessile flowers at the end of branches and the bracteoles and sepals are indistinguishable. So the new species cannot belong to section Chrysantha. Section Archecamellia is characterized by flowers solitary at the end of branches, 1116 persistent perules, 8-14 petals, glabrous or pubescent stamens connate into a cup, a glabrous or pubescent gynoecium with 3-5 loculi and 3 or 5 free styles (Sealy, 1958). The new species, C. pukhangensis, has many characteristics of section
Archecamellia, such as solitary flowers at the end of branches,11-13 indistinguishable persistent perules, pubescent stamens connate into a cup, a pubescent gynoecium with 3(or 4) loculi and 3(or 4) free styles. Because of the similarity of the features, we place C. pukhangensisin section Archecamellia (C. euphlebia, C. flava, C. petelotii and C. tonkinensis) (Sealy, 1958; Gao et al., 2005; Yang et al., 2014). The main similarities and differences of the species of section Archecamellia are summarized in Table 1.

OCRID: Dai Ngoc DO https://orcid.org/0000-0002-7741-9454; Dung Van LUONG https://orcid.org/0000-0001-5985-1975; Chinh Duy NGUYEN https://orcid.org/0000-0002-5191-8271; Son Thanh HOANG https://orcid.org/0000-0003-0351-929X; Huong Thi LE https://orcid.org/0000-0003-1123-2037; Jeong Eun HAN https://orcid.org/0000-0002-5166-1189; Han-Sol PARK https://orcid.org/0000-0002-2724-1168

\section{Acknowledgments}

This work was supported by a grant from the National Institute of Biological Resources (NIBR), funded by the Ministry of the Environment (MOE) of the Republic of Korea (NIBR201804102, NIBR201906102). We thank Nguyen Giang Hoai director of Phu Quy stone company and Phung Van Hao, a staff member of Vinh University, for helping to collect the type specimens.

\section{Conflict of Interest}

The authors declare that there are no conflicts of interests.

\section{Literature Cited}

Chang, H. T. and B. Bartholomew. 1984. Camellias. B.T. Bastford Ltd., London, 211 pp.

Gao, J., C. R. Parks and Y. Du. 2005. Collected Species of the Genus Camellia: An Illustrated Outline. Zhejiang Science and Technology Press, Guangzhou, 301 pp.

IUCN. 2017. Guidelines for using the IUCN red list categories and criteria,version 13. Retrieved March 5, 2019, available from http://www.iucnredlist.org.

Le, N. H. N. and V. D. Luong. 2016. General information about the Yellow Camellia species in Vietnam. In Proceedings of Dali International Camellia Congress. Dali, Yunnan.Pp. 80-84.

Ming, T. L. 2000. Monograph of the Genus Camellia. Yunnan Science and Technology Press, Kunming, 352 pp.

Ming, T. L. and B. Bartholomew. 2007. Theaceae. In Flora of China.Vol.12. Hippocastanaceae through Theaceae. Wu, Z.Y., P. 
H. Raven and D. Y. Hong (eds.), Science Press, Beijing and Missouri Botanical Garden Press, St. Louis, MO. Pp. 366-478.

Sealy, J. R. 1958. A Revision of the Genus Camellia. Royal Horticulture Society, London, 239 pp.
Yang, S.-X., H. Nguyen, D.-W. Zhao and Y.-M. Shui. 2014. Rediscovery of Camellia tonkinensis (Theaceae) after more than 100 years. Plant Diversity and Resources 36: 585-589. 